\section{Fluid discharge linked to bending of the incoming plate at the Mariana subduction zone}

\author{
M. Du ${ }^{1}$, X. Peng ${ }^{1 *}$, W.E. Seyfried Jr. ${ }^{2}$, K. Ta ${ }^{1}$, Z. Guo ${ }^{1}$, \\ S. Chen ${ }^{1}$, I.-M. Chou ${ }^{1,3}$, J. Li ${ }^{1}$, H. Xu ${ }^{1}$
}

\begin{abstract}
OPEN ACCESS
Abstract

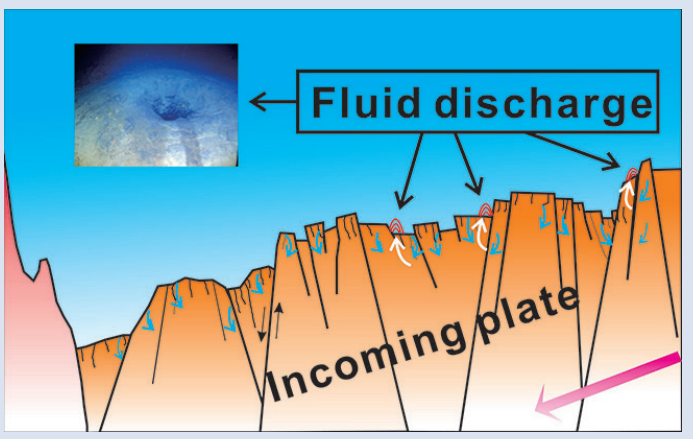

Tectonically induced bending of incoming plates at subduction zones can result in normal faulting in the upper ocean crust. Seismic surveys and numerical models indicate enhanced permeability and fluid circulation when this occurs. Yet, direct geological evidence of such effects on the seafloor is lacking. Here we report Human Occupied Vehicle (HOV) based observations of the existence of fluid discharge features on the seafloor of the incoming plate of the Mariana subduction zone. These features include fluid discharge points and associated pockmarks, which are striking, and occur in abundance in several depth related fields. The existence of Galatheid crabs, a typical seep related organism, also indicates fluid discharge from the seafloor. Alteration of the coexisting basaltic ocean crust is extensive, with iddingsite-rich muds within and overlapping the apparent fluid discharge zones. Our findings are significant in that they suggest that structural deformation of the incoming plate could substantially influence chemical exchange between the upper ocean crust and seawater in a new way. We further suggest that these fluid discharge points may represent previously unknown niches for $\mathrm{H}_{2}$-based chemolithotrophic life and microbial ecosystems at deep trenches. Observations reported here contrast both chemically and physically with serpentine mud volcano formation associated with the shallower Mariana forearc region.
\end{abstract}

Received 31 January 2019 | Accepted 9 May 2019 | Published 5 June 2019

\section{Letter}

Subduction of the oceanic crust can result in large scale structural effects, especially at the hinge point, where extension and normal faulting tend to occur (Masson, 1991). Previous studies reveal that seawater derived fluids can penetrate deeply into the ocean crust owing to the enhanced permeability that these structures provide (Ranero et al., 2003, 2005; Faccenda et al., 2009). One fate for crustal fluids is to propagate downward, hydrating the lower ocean crust and upper mantle (Ranero et al., 2003; Grevemeyer et al., 2005, 2007; Faccenda et al., 2008, 2009), while another might involve upward flow and discharge at the seafloor, made possible by tectonically induced forces. Not surprisingly, however, little direct evidence exists in support of these sorts of phenomena on the seafloor of the incoming plates at subduction zones.

Investigations of old and highly tectonised portions of the incoming plate of the southern Mariana trench were conducted using the HOV Jiaolong, which has an operating depth of $7000 \mathrm{~m}$. The HOV study resulted in the discovery of a fluid discharge field (site $\mathrm{M}$ ). The field lies on the base of a slope of a small scale fault at a water depth of $5448 \mathrm{~m}$, making it the deepest fluid discharge field yet reported for this region of the ocean floor (Fig. 1, Table S-1, Video S-1). In contrast with earlier observations of serpentine mud volcanoes in the Mariana forarc region (Hulme et al., 2010; Fryer, 2012; Plümper et al., 2017), mineralisation reported here is directly associated with variably altered mafic rocks that crop out on the trench slope, and is dominated by iddingsite (hydrous ferric silicate) not serpentine. Initial surveys of the surrounding area indicate that the field extends for about $100 \mathrm{~m}$ across the slope and hosts at least 2 small fluid discharge points and 4 pockmarks (Fig. 2). Fluid discharge points are about $1 \mathrm{~m}$ in height and 2-5 $\mathrm{m}$ in diameter, while associated pockmarks have a diameter of 3-6 m. Galatheid crabs, which are common seep-associated consumers, were observed and recovered. Similar small pockmarks were also discovered at two dive sites $\mathrm{N}$ and $\mathrm{P}$, at water depths of 6300 and $6669 \mathrm{~m}$, respectively.

\footnotetext{
1. Institute of Deep Sea Science and Engineering, Chinese Academy of Sciences, Sanya, Hainan 572000, China

2. Department of Earth Science, University of Minnesota, 310 Pillsbury Drive E, Minneapolis, Minnesota 55455, USA

954 National Center, U.S. Geological Survey, Reston, Virginia 20192, USA

Corresponding author (email: xtpeng@idsse.ac.cn)
} 

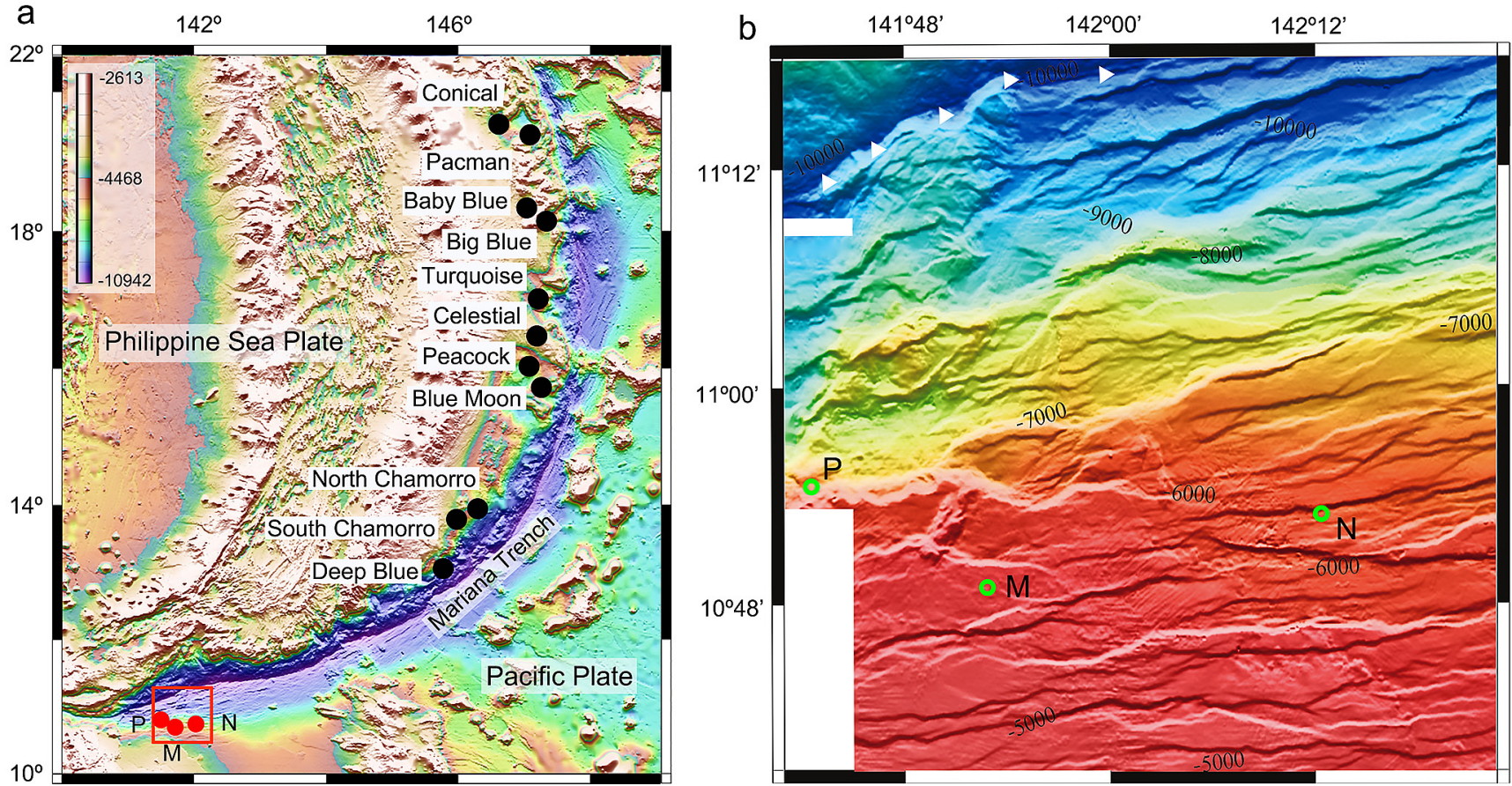

Figure 1 (a) Location of the newly discovered fluid discharge field at site $\mathrm{M}$ and two pockmarks at sites $\mathrm{N}$ and $\mathrm{P}$ (red dots) on the incoming plate of Mariana trench. (b) Enlarged shaded-relief map of red box in (a). The sites M, N and P (green circles) are situated on the base of the slopes of bending-related faults that have been extensively developed and pervasively cross the entire trench slope of the incoming plate in response to plate flexure. White triangles show the axis of the southern Mariana trench. The known serpentinite mud volcanoes (black dots in (a)) are exclusively located on the overriding plate of Mariana trench. White bars in (b) show blank areas where no multi-beam bathymetric data are available.

Raman spectroscopy, X-ray powder diffraction and optical microscopy analysis show that unaltered basement rocks in the vicinity of site $M$ contain abundant augite and labradorite, as is typical of basaltic protolith. When altered, however, iddingsite formation dominates (Figs. 3 and S-3). Iddingsite is a reddish-coloured alteration product of pyroxene and olivine and commonly exhibits variable chemical composition, while often coexisting with iron oxide and clay minerals (Edwards, 1938; Smith et al.,1987; Kuebler, 2013). Electron microprobe analyses reveal that iddingsite in altered rocks and surficial sediment recovered during the present study consists of $\mathrm{SiO}_{2}(39.8-54.3 \%), \mathrm{Fe}_{2} \mathrm{O}_{3}$ (24.6 to $34.5 \%$ ) and $\mathrm{MgO}$ (2.7-4.1\%) (Table S-2). Raman spectra show that iddingsite is intimately associated with goethite and two groups of peaks belonging to a polymerised silicate phase (Fig. S-1).

The ubiquitous presence of iddingsite at site $\mathrm{M}$ and elsewhere, together with clear evidence of iddingsite association with augite (Fig. S-2), indicates a replacement origin. In light of the augite-dominated mineral composition of basement rocks, we suggest that iddingsite is mainly derived from the alteration reaction of pyroxene rather than olivine. Based on the oxygen isotope composition of carbonates extracted from altered rocks, we estimate that temperatures at which the alteration reaction occurs range from 93 to $130{ }^{\circ} \mathrm{C}$ (Table S-3). An overall representation of chemical exchange leading to iddingsitisation can be depicted as follows:

$4 \mathrm{CaMg}_{0.5} \mathrm{Fe}_{0.5} \mathrm{Si}_{2} \mathrm{O}_{6}$ (augite) $+10 \mathrm{H}^{+}+10 \mathrm{H}_{2} \mathrm{O}=\mathrm{MgFe}_{2} \mathrm{Si}_{3}$ $\mathrm{O}_{10} \cdot 4 \mathrm{H}_{2} \mathrm{O}$ (iddingsite) $+5 \mathrm{H}_{4} \mathrm{SiO}_{4}(\mathrm{aq})+\mathrm{Mg}^{2+}+4 \mathrm{Ca}^{2+}+\mathrm{H}_{2}$.

The apparent removal of mobile alkaline earth cations and silica during iddingsite formation processes is evident (Tables S-2, S-4). The formation and release of dissolved $\mathrm{H}_{2}$, however, is of particular interest and highly significant (Table S-5). Indeed, the conspicuous abundance of dissolved hydrogen and methane in push core samples provides compelling evidence of oxidation of iron components by water reduction in the metalliferous muds on the seafloor and likely in broadly analogous chemical and mineralogical systems beneath the seafloor (Seewald et al., 2003; Seyfried et al., 2003), feeding surficial deposits- a process in keeping with the existence of moderately reducing conditions and low temperatures. This is consistent with previous analyses of crustal fluids (Cowen et al., 2003; Lin et al., 2014) and thermodynamic calculations (McCollom and Bach, 2009; Bach, 2016), which corroborated that basaltic rocks of ocean crusts could interact with circulating seawater and generate nanomolar to micromolar $\mathrm{H}_{2}$ below a temperature of $120{ }^{\circ} \mathrm{C}$. Recent laboratory experiments have also demonstrated that the transfer of electrons between Fe(II) in minerals and water promotes molecular hydrogen generation at 55 and $100{ }^{\circ} \mathrm{C}$ (Mayhew et al., 2013). The conspicuous abundance of dissolved hydrogen and methane in push core samples (Table S-4) provides compelling evidence of oxidation of iron components by water reduction in the metalliferous muds and more likely in broadly analogous chemical and mineralogical systems beneath the seafloor, feeding surficial deposits.

Fluid discharge in the southern Mariana subduction zone might be driven by tectonic overpressure under compressional regimes (Westbrook et al., 1983; Moore, 1989; Shipley et al., 1990; Kopf, 1999; Kopf et al., 2001), in keeping with the effects of fault-induced bending (Figs. 1, S-1). During Jiaolong dives, strong deformation associated with faulting in the vicinity of fluid discharge points was commonly observed (Fig. S-1). Tectonic pressure variation due to deformation is an intrinsic property of fracture under geological conditions. Strong tectonic pressure gradients are instrumental in driving local pore fluid flow during deformation (Mancktelow, 2008; Faccenda et al., 2009). Due to the tectonic overpressure, pore fluid in the upper basaltic layer could be either pumped downward producing serpentinisation or be expelled upward into the overlying layers as the slab subducts (Faccenda et al., 2009). Emplacement and sudden release of excess pore pressures could ultimately lead to the eruption of fluids on seafloor 

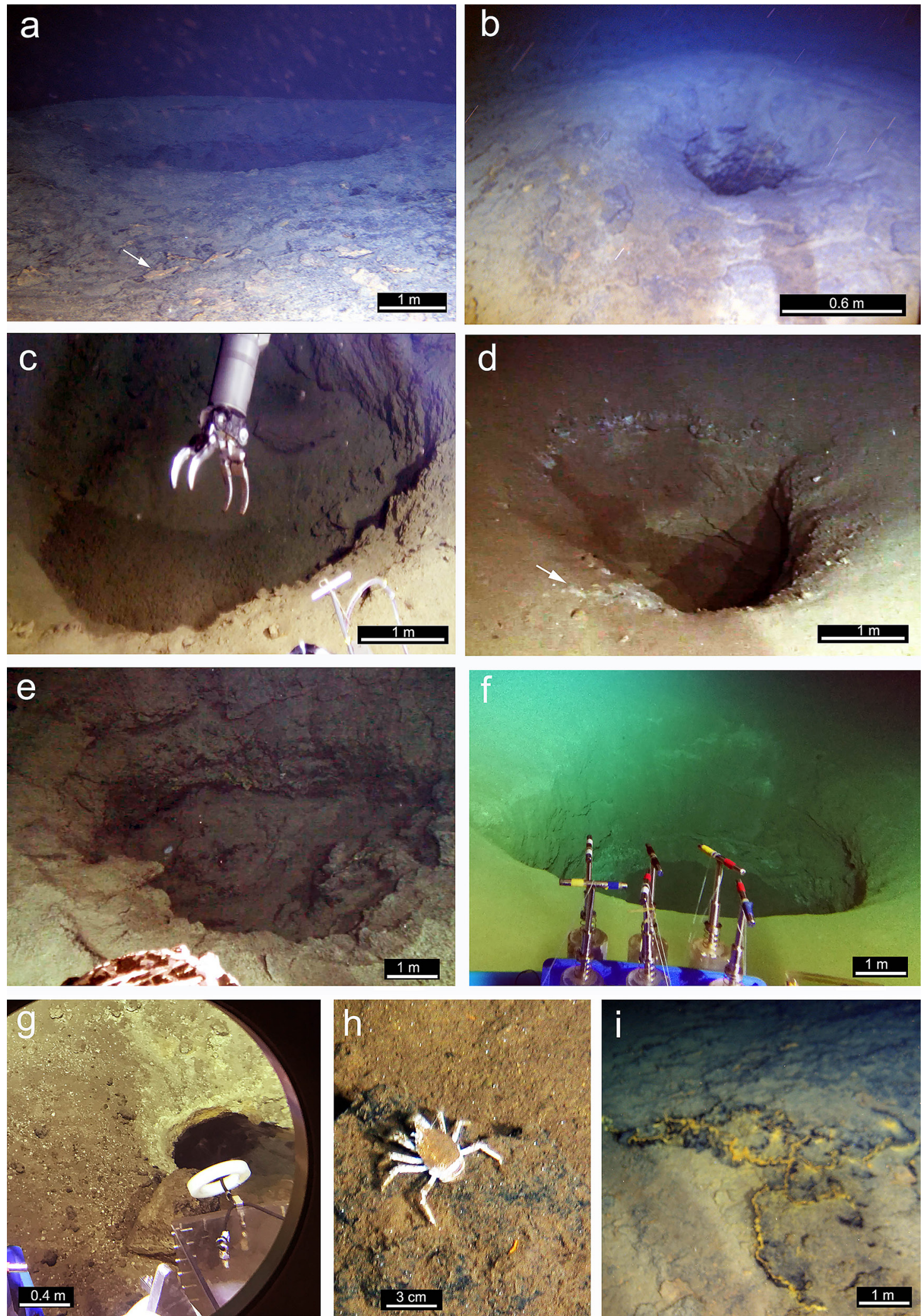

Figure 2 Fluid discharge points and pockmarks in the southern Mariana trench. (a) A small fluid discharge point (\#JL114-1 at 5445 m) in the eastern portion of site $\mathrm{M}$. The yellow-reddish solidified materials marked by arrows at the margin of the crater consist mostly of iddingsite. (b) Close-up of the top of a fluid discharge point (\#IL114-1 at $5445 \mathrm{~m}$ ) showing a feeder channel with a diameter of $\sim$ $0.6 \mathrm{~m}$. (c) A pockmark (\#JL115-1 at $5445 \mathrm{~m}$ ) of $\sim 5 \mathrm{~m}$ in diameter in the western portion of site M. The muds are primarily composed of iddingsite. (d) A shallow pockmark (\#JL114-2 at $5445 \mathrm{~m}$ ) that consists primarily of iddingiste in the western portion of site M. White materials marked by arrows are zeolites that are also low grade alteration products of basaltic rocks. (e) A fluid discharge point (\#IL114-3 at $5445 \mathrm{~m}$ ) with a blocked feeder channel in the eastern portion of site M. (f) An iddingsite pockmark (\#JL144-1 at 6300 m) with a diameter of $\sim 4 \mathrm{~m}$ and a depth of $\sim 3 \mathrm{~m}$ at site $\mathrm{N}$. (g) A small iddingsite pockmark (\#JL146-1 at $6669 \mathrm{~m}$ ) at site P. (h) A white Galatheid crab on a dark manganese crust that forms within iddingsite-rich muds at site $\mathrm{M}$. (i) Blanket-like iddingsite muds with a dark manganese coating on the base of a fluid discharge point at site $\mathrm{M}$. 

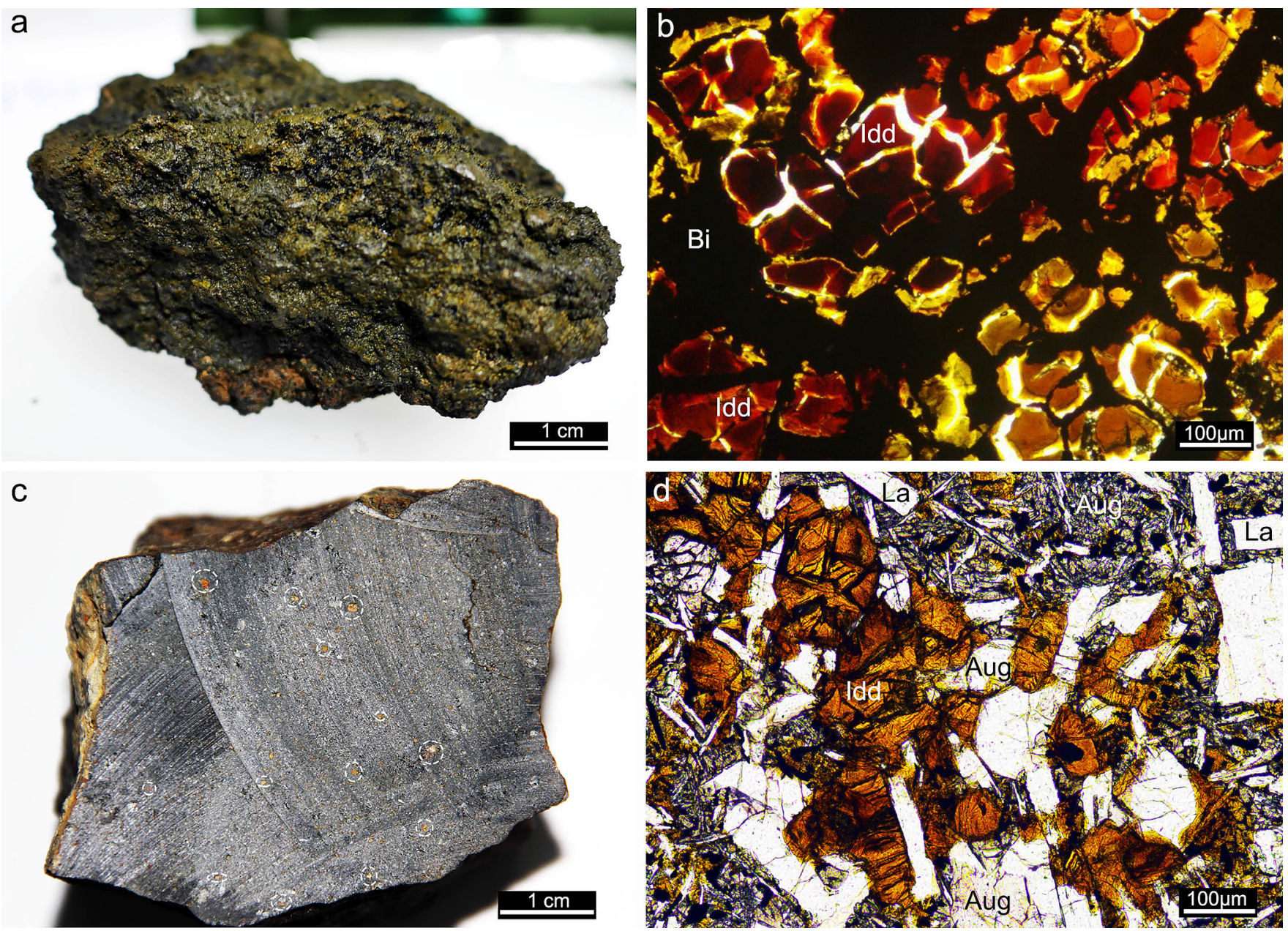

Figure 3 Highly altered and partly altered basement rocks associated with fluid discharge points. (a) A dark-green, fragile and highly altered basement rock (\#JL115-Rock-11) recovered from site M. (b) Image in plane polarised light showing that the rock in (a) exhibits a mesh-like structure composed of reddish iddingsite (Idd) and black birnessite (Bi). The latter probably precipitated from seawater along fractures of the altered rocks in the late stage. (c) A partly altered basement rock recovered from the vicinity of site M (\#JL116-Rock-6). Dotted cycles point out reddish iddingsite in the basaltic host. (d) Image in plane polarised light showing that the rock in (c) is primarily composed of augite (Aug), labradorite (La) and a cluster of reddish iddingsite (Idd).

and the formation of fluid discharge points and pockmarks observed here (Brown, 1990; Clennell, 1992; Dimitrov et al., 2002; Kopf, 2002; Dimitrov and Woodside, 2003). Earthquakes, which commonly occur on the outer rise region of the incoming plate in subduction zones (Christensen and Ruff, 1988; Tilmann et al., 2008), might also trigger fluid discharge of the type envisaged.

Assuming $\mathrm{H}_{2}$ is generated via the iddingsitisation reaction as proposed, it can be expected to fuel $\mathrm{H}_{2}$-utilising microorganisms within underlying rocks and iddingsite-rich muds. The phylogenetic diversity of Bacteria and Archaea revealed by high throughput sequencing in altered rocks shows that the populations of $\mathrm{H}_{2}$-utilising microorganisms drive some of the uniqueness in this habitat (Supplementary Information; Figs. S-3, S-4). In particular, hydrogenotrophic methanogens were commonly identified at the species to order levels in Archaea. Hydrogenotrophic methanogen, for example Methanococcus maripaludis, produces methane as a product of energy metabolism according to the reaction $4 \mathrm{H}_{2}+\mathrm{CO}_{2} \rightarrow \mathrm{CH}_{4}+2 \mathrm{H}_{2} \mathrm{O}$ (Jones et al.,1983). In addition, exclusively hydrogentrophic methanogens such as Methanomicrobiales, Methanobacteriales, Methanopyrales, and Methanococcales, together with functional enzyme-encoding genes involved in hydrogenotrophic methanogenesis pathway, were identified by metagenomic analyses of the iddingsite-rich muds (Figs. S-5, S-6). These results reveal that $\mathrm{H}_{2}$-ultilising chemolithotrophs reside in the fluid discharge field.
Mineralised mud accumulations and pockmarks reported here are examples of a previously unknown type of fluid discharge system that can be linked to bending of the incoming plate. Based on the widespread presence of faults, along with associated deformational features on the trench bottom, as observed by Jiaolong dives, we anticipate that systems similar to this may be common in trenches at other plate boundaries. Thus, because tectonic forces characteristic of the Mariana trench are likely at other oceanic trenches, similar fluid discharge might be more widespread at seafloor along global trenches than presently envisaged. This could have a substantial influence on the magnitude of chemical exchange between the upper ocean crust and seawater with important implications for global geochemical cycles (Table S-4). Perhaps the most important observation reported in this study is the $\mathrm{H}_{2}$-based chemolithotrophic microbial ecosystem (Stevens and McKinley, 1995; Chapelle et al., 2002) coexisting with, if not thriving, in the iddingsite-rich fluid discharge points on the floor and possibly sub-seafloor of the Mariana subduction zone.

\section{Acknowledgements}

We are very grateful to the pilots and crew of the RVXYH09-Jiaolong for their professional service during this cruise. Funding for this study was provided by the Strategic Priority Research 
Program of the Chinese Academy of Sciences (XDB06020000) and the National key research and development plan of China (2016YFC0304900, 2016YFC0302301 and 2016YFC0300503)

Editor: Eric H. Oelkers

\section{Additional Information}

Supplementary Information accompanies this letter at http:// www.geochemicalperspectivesletters.org/article1916.

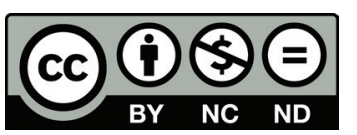

This work is distributed under the Creative Commons Attribution Non-Commercial No-Derivatives 4.0 License, which permits unrestricted distribution provided the original author and source are credited. The material may not be adapted (remixed, transformed or built upon) or used for commercial purposes without written permission from the author. Additional information is available at http://www.geochemicalperspectivesletters.org/ copyright-and-permissions.

Cite this letter as: Du, M., Peng, X., Seyfried Jr., W.E., Ta, K., Guo, Z., Chen, S., Chou, I.-M., Li, J., Xu, H. (2019) Fluid discharge linked to bending of the incoming plate at the Mariana subduction zone. Geochem. Persp. Let. 11, 1-5.

\section{References}

BACH, W. (2016) Some compositional and kinetic controls on the bioenergetics landscapes in oceanic basement. Frontiers in Microbiology 7, 1-8.

BROWN, K.M. (1990) Nature and hydrogeologic significance of mud diapirs and diatremes for accretionary systems, Journal of Geophysical Research $95,8969-8982$.

Chapelle, F.H., O'Neill, K., Bradley, P.M., Methé, B.A., Ciufo, S.A. KNoBel, L.L., LovLEY, D.R. (2002) A hydrogen-based subsurface microbial community dominated by methanogens. Nature 415, 312-315.

Christensen, D.H., RUFF, L.J. (1988) Seismic coupling and outer rise earthquakes. Journal of Geophysical Research 93, 13421-13444.

CLENNELL, M.B. (1992) The mélanges of Sabah, Malaysia. Ph.D thesis, Univer sity of London, London, UK.

Cowen, J.P., Giovannoni, S.J., Kenig, F., Johnson, H.P., Butterfield, D., Rappé, M.S., Hutnak, M., LAM, P. (2003) Fluids from aging ocean crust that support microbial life. Science 299, 120-123.

DimitROV, L.I. (2002) Mud volcanoes - the most important pathway for degassing deeply buried sediments. Earth-Science Reviews 59, 49-76.

Dimitrov, L.I., WoODSIDE, J. (2003) Deep sea pockmark environments in the eastern Mediterranean. Marine Geology 195, 263-280.

EDWARDS, A.B. (1938) The formation of iddingsite. American Mineralogist 23, $277-281$

Faccenda, M., Burlini, L., Gerya, T.V., Mainprice, D. (2008) Fault-induced seismic anisotropy by hydration in subducting oceanic plates. Nature 455, 1097-1100.

FACCENDA, M., Gerya, T.V., Burlini L. (2009) Deep slab hydration induced by bending-related variations in tectonic pressure. Nature Geoscience 2, 279-293.

FRYER, P. (2012) Serpentinite mud volcanism: observations, processes, and implications. Annual Review of Marine Science 4, 345-373.

Grevemeyer, I., Kaul, N., Diaz-Naveas, J.L., Villinger, H.W., Ranero, C.R., REICHERT, C. (2005) Heat flow and bending-related faulting at subduction trenches: Case studies offshore of Nicaragua and Central Chile. Earth and Planetary Science Letters 236, 238-248.

Grevemeyer, I., Ranero, C.R., Flueh, E.R., Kläschen, D., Bialas, J. (2007) Passive and active seismological study of bending-related faulting and mantle serpentinization at the Middle America trench Earth and Planetary Science Letters 258, 528-542.

Hulme, S.M., Wheat, C.G., Fryer, P., Mottl, M.J. (2010) Pore water chemistry of the Mariana serpentinite mud volcanoes: A window to the seismogenic zone. Geochemistry, Geophysics, Geosystems 11, 1
Jones, W.J. PAYnter, M.J.B., GUPtA, R. (1983) Characterization of Methanococcus maripaludis sp. nov., a new methanogen isolated from salt marsh sediment. Archives of Microbiology 135, 91-97.

Kopf, A. (1999) Fate of sediment during plate convergence at the Mediterranean Ridge accretionary complex: Volume balance of mud extrusion versus subduction-accretion. Geology 27, 87-90.

Kopf, A. (2002) Significance of mud volcanism. Reviews of Geophysics 40, 2-49.

Kopf, A., Klaeschen, D., Mascle, J. (2001) Extreme efficiency of mud volcanism in dewatering accretionary prisms. Earth and Planetary Science Letters 189, 295-313.

KUEBLER, K.E. (2013) A comparison of the iddingsite alteration products in two terrestrial basalts and the Allan Hills 77005 martian meteorite using Raman spectroscopy and electron microprobe analyses. Journal of Geophysical Research 118, 803-830.

Lin, H.T., Cowen, J.P., Olson, E.J., Lilley, M.D., Jungbluth, S.P., WiLson, S.T., RAppé, M.S. (2014) Dissolved hydrogen and methane in the oceanic basaltic biosphere. Earth and Planetary Science Letters $405,62-73$.

MANCKTELOW, N. (2008) Tectonic pressure: Theoretical concepts and modeled examples. Lithos 103, 149-177.

MASsON, D.G. (1991) Fault patterns at outer trench walls. Marine Geophysical Research 13, 209-225.

Mayhew, L.E., Ellison, E.T., McCollom, T.M., Trainor T.P., TeMPLETON, A.S. (2013) Hydrogen generation from low-temperature water-rock reactions. Nature Geoscience 6, 478-484.

MCCOLLOM, T.M., BACH, W. (2009). Thermodynamic constraints on hydrogen generation during serpentinization of ultramafic rocks. Geochimica et Cosmochimica Acta 73, 856-875

MoorE, J.C. (1989) Tectonics and hydrogeology of accretionary prisms: Role of the décollement zone. Journal of Structural Geology 11, 95-106.

Plümper, O., King, H.E., Geisler, T., LiU, Y., PABst, S., SAVOV, I.P., Rost, D., ZACK, T. (2017) Subduction zone forearc serpentinites as incubators for deep microbial life. Proceedings of the National Academy of Sciences of the United States of America, doi/10.1073/pnas.1612147114.

Ranero, C.R., Phipps Morgan, J., Reichert, C. (2003) Bending-realted faulting and mantle serpentinization at the Middle America trench. Nature 425, 367-373.

Ranero, C.R., Villaseñor, A., Phipps Morgan, J., Weinrebe, W. (2005) Relationship between bend-faulting at trenches and intermediate-depth seismicity. Geochemistry, Geophysics, Geosystems 6, Q12002.

Seewald, J., CRuse, A., Saccocia, P. (2003) Aqueous volatiles in hydrothermal fluids from the Main Endeavour Field, northern Juan de Fuca Ridge: temporal variability following earthquake activity. Earth and Planetary Science Letters 216, 575-590.

Seyfried, W., Seewald, J., Berndt, M., Ding, K., Foustoukos, D. (2003) Chemistry of hydrothermal vent fluids from the Main Endeavour Field, northern Juan de Fuca Ridge: geochemical controls in the aftermath of June 1999 seismic events. Journal of Geophysical Research, Solid Earth 108, 978-2012.

Shipley, T.H., Stoffa, P.L., DEAN, D.F. (1990) Underthrust sediments, fluid migration paths, and mud volcanoes associated with the accretionary wedge off Costa Rica, Middle America trench. Journal of Geophysical Research 95, 8743-8752.

Smith, K.L., Milnes A.R., Eggleton, R.A. (1987) Weathering of basalt: formation of iddingsite. Clays and Clay Minerals 35, 418-428.

STEvens, T.O., McKInLEY, J.P. (1995) Lithoautotrophic microbial ecosystems in deep basalt aquifers. Science 270, 450-452.

Tilmann, F.J., Grevemeyer, I., Flueh, E.R., Dahm, T., Gossler, J. (2008) Seismicity in the outer rise offshore southern Chile: Indication of fluid effects in crust and mantle. Earth and Planetary Science Letters 269, $41-55$.

WestbrooK, G.K., Smith, M.J. (1983) Long décollements and mud volcanoes: Evidence from the Barbados Ridge Complex for the role of high pore-fluid pressure in the development of an accretionary complex. Geology 11, 279-283 